\title{
Man or Machine? Liberalism Old and New: From Wilhelm von Humboldt to the Teachings of Ludwig von Mises and Friedrich August von Hayek
}

\author{
Nahyan Niazi \\ Department of Philosophy, University of Lucerne, Switzerland
}

Copyright $(2018$ by authors, all rights reserved. Authors agree that this article remains permanently open access under the terms of the Creative Commons Attribution License 4.0 International License

\begin{abstract}
The attraction of the Austrian school's liberalism lies in its seemingly clear-cut guidelines in deciding what the limits of government activities should be - namely, to provide security and peace, and to uphold the laws, especially property laws, all in order to ensure the unhampered functioning of the market system. In this paper, I argue that the Austrian brand of liberalism as represented by Ludwig von Mises (LvM) and Friedrich August von Hayek $(\mathrm{FAvH})$ is as much concerned with checking and curtailing government activities as it is with regulating the human mind. Deregulation of the market and regulation of the mind go hand in hand with the instrumental expansion of market competition resulting in a specific mode of production and way of thinking. From an ethical point of view, the supreme role of market competition has to be called into question as it not only narrows the choices of feasible ways of life, especially to those not endowed with capital, but also conditions the way we think (mind control). To highlight this critique of the Austrian brand of liberalism I compare it to the perfectionism of the classic liberal thinker Wilhelm von Humboldt $(\mathrm{WvH})$, whose liberalism is wrongly believed to be in accordance with LvM and FAvH's liberalism. WvH avoided formulating a liberal vision of a polity without a rich perfectionist conception of human nature. This conception provides the normative backdrop of his entire political thinking. Without WvH's finespun understanding of human nature and care for self-realization the reign of competitive markets transforms liberalism into an alienating force regulating the human mind in accordance with consumerism and, as $\mathrm{WvH}$ would say, turning man into a machine.
\end{abstract}

Keywords Liberalism, Perfectionism, Market Competition, Self-realization, Alienation, (De-)Regulation, Human Mind

\section{Introduction}

Reaching far back before liberalism's advent as a coherent and influential political philosophy, Plato's Politeia discussed the role the state should play in forming people's lives. Read literally, he provided a blueprint of what he thought an ideal state ought to be. The anti-liberal aspects of Plato's vision should not cloud his simple, rational and timeless insight that there exists an interplay between the human soul and the specific form of the existing state, the constitution [1]. For every type of human character and its mores, there is a corresponding constitution [2]. Plato then proceeds to describe a sequence of constitutions following each other (metabolê politeionn) [3], set in motion by the miscalculations of the philosophers in charge that, over time, made the steady state of the ideal constitution, along with the corresponding types of moral characters, degrade into pathological constitutional forms [4].

The Austrian-American economist Ludwig von Mises' (LvM) defence of a competitive capitalist market system against interventionist and socialist schemes of organizing production follows astonishingly similar lines of argument to Plato. According to LvM, the role of the state lies in safeguarding the unhampered functioning of the market economy. Only the latter allows for "monetary economic calculation", which "is the intellectual basis of the market" [5]. The market replaces Plato's philosophers as an instrument of rational calculation needed to direct men into their proper societal positions (of production) - with the difference that the market never errs. The market maps the alleged autonomous decisions of market subjects to prices which signal how and what to produce. This allows all productive entities to execute economic calculations which in turn guide their decision-making [6]. If the market is hampered by interventionist enterprises intent on altering pure market outcomes, prices suffer a loss of content needed to guide production. Just as in Plato's ideal state in 
which the different classes should not presume to meddle in each other's affairs but rather keep to their natural given functions [7], so, too, in LvM's view the state should not meddle in the market sphere. Obviously, this also means that democratic meddling in the sacred sphere, be it that of the philosopher king's or of the market's decision making, should not be allowed [8]. That this kind of reasoning is still very influential can be seen by the German finance minister Wolfgang Schäuble's reply to the Greek finance minister Yannis Varoufakis' efforts to renegotiate the "Greek economic plan" on behalf of his people [9]: "Elections cannot be allowed to change an economic programme of a member state!" LvM recounts the liberal mission as a counter-attack against absolutism's self-proclaimed divine mission: "Observe the function of the market system, they [the liberals, NN] said, and you will discover in it too the finger of God" [10].

With reference to David Hume, LvM, like Plato, stresses the pre-eminence of ideas. According to LvM, power "ultimately rests, not upon material force, but upon ideas", a statement that turns Marxist theory on its head [11]. "All interhuman relations are the offshoot of ideas and the conduct of individuals directed by these ideas" [12]. Hence LvM, like Plato, concludes that man's state of mind is of crucial importance in determining the body politic: "That socialist men, for whom arithmetic [due to a lack of unhampered competitive market pricing, $\mathrm{NN}$ ] will be of no use in planning action, will differ entirely in their mentality and in their mode of thinking from our contemporaries" [13]. Somewhat analogous to Plato's elitist state, LvM believes that only a small minority of the people are wise, while "the masses, the hosts of common men, do not conceive any ideas, sound or unsound. They only choose between the ideologies developed by the intellectual leaders of mankind" [14]. LvM's greatest fear is the metabolê politeiôn from a liberal capitalist state to a socialist one. Long before Margaret Thatcher's TINA (there is no alternative [to the market system]) Ludwig von Mises declared that there was nothing in-between socialism and liberalism, and that socialism did not work [15]. Hence the pure market mechanism can only serve as a machine for generating material wealth and innovation if it ranks supreme and is not meddled with by democratic interventionist endeavours that aim to impress ideas (of social justice) external to the market onto its results, which, in turn, skew market signals that are crucial for production planning. This is usually seen as a deregulation strategy on the part of market liberalism, one that secures the private sphere against the state (each to his own), balances private and state power and, in the process, secures democracy [16]. What is usually overlooked, in my opinion, is the role that the market mechanism is meant to play in terms of mind control. Unhampered market competition produces not only wealth (especially for some), but also a certain type of citizen.

When LvM and his disciple Friedrich August von Hayek
$(\mathrm{FAvH})$ argue for the state to be restricted to providing the framework needed for markets to function efficiently setting the tone for neoliberal thought -, this kind of market liberalism itself needs to be scrutinised from the Platonic standpoint: what kind of man does the competitive market system breed? Or, in more modern terms: how does the incentive scheme of a competitive market system as devised by the more radical Austrian school influence man's way of thinking, self-perception and value system? It makes sense to compare the ideal man of a competitive market system to the ideal man that the classical liberals had in mind. This allows for a normative evaluation of the competitve market system, which will be the sole focus of this article. For LvM and especially for FAvH, Wilhelm von Humboldt (WvH) was "Germany's greatest theoretician of freedom" [17]. Especially FAvH (and hence also LvM) is explicitly thought of as standing in the genealogy of Humboldt's liberalism, carrying the torch of freedom into the new millennium [18]. In this essay I contend that WvH's idea of "Bildung" (here translated as "self-realization") is not compatible with the radical conception of competitive market systems ("catallactic competition" [19]) as propagated by LvM and FAvH [20].

\section{Methodology and Preliminary Remarks}

By referring to Plato's rationale in the Introduction, my aim was to emphasize that any serious political philosophy has to consider the interplay of both the psychological-anthropological and sociological spheres. Noam Chomsky is right in remarking that "an animating vision [of a future society] must rest on some conception of human nature" [21]. Every political philosophy can be traced back to a conception of human nature which in turn, no matter how vaguely, defines the goal of human life mostly in some relation to moral conduct and the idea of happiness.

In the following chapters I compare LvM's and FAvH's implicit conception of the good life to that of Wilhelm von Humboldt's. I shall begin by deducing the ideal archetype of man from LvM's conception of the catallaxy (competitive market system) which for him comprises the necessary component of any free philosophical ideology. Although there are differences to be found between LvM's and FAvH's theoretical positions, I believe these to be negligible in respect to the conception of human nature and the function of man in the catallaxy [22]. This will allow me to focus on LvM, while only referencing FAvH for the purposes of elucidation or complementarity. Both use the term "catallaxy" to describe the decentralized spontaneous "order that results from the adjustment of many separate private enterprises under conditions of [unhampered] market" competition (catallactic competition) [23]. The precondition is private ownership of the means of 
production.

A normative critique of a philosophical conception of an ideal political community can roughly follow two lines - a simplified approach connected to the method of immanent critique:... from the logic of a system, reflected in the incentive system it devises, follow the functions man has to adopt to excel within the system devised (conception of ideal man) - or vice versa. These ideal functional features are condensed into a way of thinking (mind-set). If the logic of a devised system is coherent with the implicit or explicit conception of ideal man of the same system, the critique must be external. "External" here means that the normative conception of ideal man is not convincing. The critique is "internal" if there is a dissonance within a philosophical system between the system's logic and its conception of human nature (false theoretical self-image).

As LvM's and FAvH's political philosophy is in itself reasonably conclusive - which in general is no easy task to accomplish and surely also accounts for its impressive ideological impact - the critique will be mainly external (quadrant I in Table 1). LvM and FAvH state that the catallaxy produces the highest amount of all the demanded means for personal ends, hence in their view facilitating individual self-realization. But this should not be confused with WvH's understanding of self-realization. LvM's and FAvH's focal point, as I will argue, is rather to safeguard the profitable production of means than to enable the enriching pursuit of individual ends. I will focus on what kind of mindset humans have to adopt according to LvM and FAvH in order to preserve the catallaxy and for man to excel within the catallactic system. This mindset is interpreted as an expression of the ideal subject/archetype of the catallaxy. Wilhelm von Humboldt's conception of "Bildung" or "self-realization" will be the external normative source of critique.

Table1. Types of Critique.

\begin{tabular}{|c|c|c|}
\hline & $\begin{array}{c}\text { System A: } \\
\text { Catallaxy }\end{array}$ & $\begin{array}{c}\text { System B: } \\
\text { Liberalism (or Mix } \\
\text { of Liberalism and } \\
\text { Socialism) }\end{array}$ \\
\hline $\begin{array}{c}\text { Corresponding Concept } \\
\text { A of Human Nature } \\
\text { applies }\end{array}$ & $\begin{array}{c}\text { I: Coherence } \\
\text { (type of } \\
\text { critique: } \\
\text { external) }\end{array}$ & $\begin{array}{c}\text { II: Dissonance } \\
\text { (type of critique: } \\
\text { internal) }\end{array}$ \\
\hline $\begin{array}{c}\text { Corresponding Concept } \\
\text { B of Human Nature } \\
\text { applies }\end{array}$ & $\begin{array}{c}\text { III: Dissonance } \\
\text { (type of critique: } \\
\text { internal) }\end{array}$ & $\begin{array}{c}\text { IV: Coherence } \\
\text { (type of critique: } \\
\text { external) }\end{array}$ \\
\hline
\end{tabular}

Two further preliminary remarks are necessary. Firstly, LvM contends that liberalism (and its capitalist market economy) as he understands it is an ideology that is thoroughly based on science. The science LvM is talking about is economics, and economics has, according to LvM, shown that no viable alternative social order exists that can integrate the free agents of a society that is based on the division of labour into an efficient scheme. Therefore, any value judgement or ethical critique of the liberal capitalist system is idle [24]. This argument is diametrically opposed to WvH's approach to the question of the proper limits of state power. For $\mathrm{WvH}$, it is the fullest development of man's innate human capacities as a whole that marks the starting point around which a philosopher must build his system [25]. Even if, for the sake of argument, LvM were right about the inevitability of the competitive market system, if there are indications that humans could develop into an even higher, even richer and even more fulfilling state of being than under the capitalist scheme (signs of alienation), from an ethical standpoint the impetus to improve or to adjust the system remains. There might be big differences between a (more) "pure" market system and a regulated one in respect to the individual's well-being. And why, from a (maybe naïve but arguable) bio-logical standpoint, through the process of evolution should a natural being develop a positive potentiality whose unfolding it is not able to organize socially? Furthermore, LvM states that "the system of market economy has never been fully and purely tried", but "by and large a general tendency toward the abolition of institutions hindering the operation of the market economy" prevailed in Western civilizations [26]. LvM's positive account of "the laissez-faire principle of Manchasterism" is by no means undisputed [27]. One might argue, for instance, that as Rudolf Rocker and many others from the earlier stages of capitalism suggest, it was only through the hard-won battles of the proletariat for a larger share of the spoils that capitalism was even rendered viable [28]. If "the market economy is the product of a long evolutionary process", why should it not further evolve into something better-fitted to human nature [29]? How can anybody presume to know the evolutionary end stage (without even trying to improve the current state of affairs)? The motivation to even search for a better system obviously must be rooted in a different conception of human nature and of the good life from that of LvM and FAvH. And finally, even if it were only the capitalist market economy that was able to supply everyone with the greatest diversity and largest quantity of material goods, the issue of value judgement would still arise. How much time should one invest in the production of means and how much in the application of these means for personal ends? (And should we be unconcerned about how these means are produced?) From the principles guiding market exchange put forth by LvM and FAvH, I do not see how the capitalist market system could sui generis decide this trade-off without regulations being put in place, unless one assumes that the drive towards higher productivity will stop short of increasing working hours when a worker's health - and hence his productivity - is at risk - an action not commonly attributed to capitalism and a rather inappropriate gamble with people's health.

Secondly, one could object that the functional features a system requires men to adopt do not entirely define human beings. Hence one could maintain, as LvM does, that 
market theory is not concerned with ends or with a complete and rich vision of what human beings ought to be. True, but this objection cannot ward off categorical criticism as we are discussing the operating mode of a system. Work constitutes a large part of a person's life and, particularly in the perfectionist tradition from Aristotle to Humboldt up to the present day, it has been seen as a means of self-realization and source of happiness.

I shall now proceed to analyze LvM's (and FAvH's) conception of man which begins with the second objection and its distinction of internal and external needs, of which the latter are meant to be solely catered for in competitive markets.

\section{Man as Machine? LvM and FAvH as Masters of Regulation}

For LvM, "liberalism as a doctrine aims altogether at the behavior of men". It is only concerned with man's "external material welfare" and not with his "inner, mental or metaphysical needs". It promises to supply humans with "all kind of things of the outside world" and not with "happiness and inner satisfaction" [30]. He sums up liberalism's goal as "establishing the external preconditions for the flourishing of the inner life" [31]. Marxism cherishes the illusion that work in a socialist society is not a burden but is full of relish [32]. These incipient remarks serve LvM to address the dissatisfaction of the masses with the workings of the competitive market system, a problem for capitalism facing democratic party systems. "The uncouth hordes of common men [...] judge everybody from the point of view of the satisfaction of their desires" [33]. According to LvM, as the masses, on the one hand, cast their economic vote for the most efficient producers by buying their products and, on the other hand, resent the profits the capitalists accrue by catering to the masses' own demands, they contradict themselves and overlook that "capital is accumulated by thrift and saving" of the successful capitalists which, in turn, enables them to further meet mass demands [34]. Only within a market economy "the biological, moral, and intellectual inequality of men" is harnessed in such a way that "the better people are forced by the instrumentality of the profit-and-loss system to serve the concerns of everybody" [35]. The endless innovative drive of the market would cease to exist if not for the better man, "the promoter and his eagerness to make profits as large as possible" [36]. For LvM, the market system is truly democratic [37]. This line of argument is somewhat reminiscent of Plato's conception of justice. The natural inequality of men justifies their functional differentiation to serve the body politic as a whole [38]. This explains why the diffusion of the right ideas is crucial for capitalism's survival: "There is no other means to safeguard a propitious development of human affairs than to make the masses of inferior people adopt the ideas of the elite" by influencing public opinion [39]. "The main objective of praxeology and economics is to substitute consistent correct ideologies for" the populace's fallacious ideas [40]. People have to be "mentally and intellectually" updated "to life in the market society" [41]. In a capitalist market system, man has to learn to become self-reliant and to shoulder his own lot. To do so, he needs self-awareness and the study of "the principles of societal cooperation of mankind" [42]. These principles point to the competitive market system which, in turn, is based on private property and the division of labour (and equality before the law) leading to "market exchange of goods and services" [43]. The following sections will analyse these features (private property and freedom, division of labour, competition, human nature and the human mind) in turn.

Private property (ownership of the means of production) creates a sphere of freedom, where the autonomy of the individual is safeguarded against the state. This autonomy means that man's freedom is framed within the market system where competition is the rule of the game: "The freedom of man under capitalism is an effect of competition" [44]. This kind of freedom that private ownership of the means of production establishes is seen by LvM as a necessary prerequisite for individual profit-induced initiative and flourishing that permit higher levels of productivity than in any other system [45]. "We may define freedom as that state of affairs in which the individual's discretion to choose is not constrained by governmental violence beyond the margin within the praxeological law restricts it anyway" [46]. The government's essential function is to guarantee "the smooth operation of the market economy" against any disturbance [47]. Even "constitutions, bills of rights, and laws" are meant to safeguard the market against the government [48]. People are free to flourish in tune with the praxeological laws of economics set in motion by private property that is in the iron grip of market competition. Clearly, then, private property and capitalist market exchange put freedom under the spell of market competition. Any viable form of self-realization will have to align with the logic of market competition.

As we have seen, to LvM, ideas are the core element of societal schemes involving human cooperation [49]. "Society is a product of human action. Human action is directed by ideologies" [50]. Most people are not capable of logical reasoning, let alone imaginative foresight, and they therefore fall into the trap of short-term thinking, opting "for immediate benefits instead of higher long-term rents" [51]. They are not able to see that capitalism (with its adjustment mechanisms that invoke insecurities) is a cooperative scheme that is beneficial not only to the owners of the means of production, but to everyone (at least in the medium to long-term) [52]. Development was only possible through "the discovery of the principle of the higher productivity of cooperation under a system of 
the division of labor" [53]. The market system organizes the division of labour through private property relations. "Everybody acts on his own behalf; but everybody's actions aim at the satisfaction of other people's needs as well as at the satisfaction of his own" [54]. Thus, the division of labour is also an aspect of freedom as "the member of a contractual society is free because he serves others only in serving himself" [55]. The market simultaneously signals (through prices) to the individual where to channel his energies in order to best serve people's demands. For LvM, this does not amount to coercion [56]. "The higher productivity of cooperation under division of labor makes society the foremost means of every individual for the attainment of his own ends whatever they may be" [57]. But cooperation through unhampered market exchange, i.e. being a market player, also means to serve consumer demands by constantly adjusting production in the race for comparatively higher profits. (I have chosen not to pursue the important question of whether production is strictly demand driven.) But "the driving force of the market process is provided neither by the consumers nor by the owners of the means of production - land, capital goods, and labor - but by the promoting and speculating entrepreneurs" [58]. The speculators seem to be the missing link in the market system of the "functional" division of labour, i.e., of workers, scientist-investors, owners of capital (savers) and entrepreneurs [59]. Obviously these functions can overlap. Speculating entrepreneurs "approach the owners of the factors of production, and their competition sends the prices of these factors up to the limit corresponding to their anticipation of the future prices of the products. They approach the consumers, and their competition forces prices of consumers' goods down to the point at which the whole supply can be sold" [60]. LvM sums up: "There are always profits to be earned by somebody. The speculators are always enticed by the expectation of profit" [61]. Only the profit-seeking drive of market competition that is ever on the watch for "the most profitable investment opportunities", "the laissez-faire principle of Machesterism", could lead to "huge capital accumulation" that can fund scientific-technological innovations that can be transformed into goods which, in turn, will improve the living standards of the masses [62]. In this way, human acquisitiveness is harnessed and put to the good use of mankind - a line of argument excised from Adam Smith's The Wealth of Nations. Thus "modern industrialization [an ongoing process nowadays for example represented by biotechnology], the practical employment of the discoveries of the natural sciences, is intellectually conditioned [highlighted, NN] by the operation of a market economy" [63].

This intellectual or mental conditioning through market competition needs further examination. The preceding chapters served to point out that neither private property nor the division of labour (alone) necessarily leads to the kinds of market pressure LvM and FAvH deem necessary for progress. Unhampered market competition seems to be the pivotal point of the catallaxy that sets the specific capitalist drive for accumulation and its concurrent way of life in motion. Market competition does not permit one to rest on one's laurels; instead, it exerts pressure on all levels of society through profit-seeking, especially on the owners of the means of production [64]. For LvM and $\mathrm{FAvH}$, universal competition guarantees progress and ensures that needs are met democratically, according to demand. Universal competition reflects what goods people want, and what they choose to spend their money on (monetary vote). Even the rich fear this competition because it is a dynamic process that rewards the far-seeing investor, speculator and entrepreneur [65]. Any understanding of the "cooperative" competition of the market system requires some knowledge of human nature. The constant push for more interlocks with man's natural drive towards ever-improving his material welfare. According to LvM, all of man's actions are due to man's drive for ever-improving his material condition [66]. "The incentive that impels a man to act is always some uneasiness" [67]. LvM is solely concerned "with the praxeological side of human action" and not with man's ultimate ends [68]. The market universe is not in the business of supplying ends. Accordingly, praxeology's "findings are valid for all kinds of action irrespective of the ends aimed at. It is a science of means, not of ends" [69]. Praxeology for LvM is nonetheless teleological and eudaimonistic: it relies strictly on causality and aims at removing uneasiness "to make the acting men feel happier" [70]. By defining man's motive for action in the negative by saying it is triggered by man's universal aim to remove uneasiness, LvM is able to define man's actions as "necessarily always selfish. Even an action directly aiming at the improvement of other people's conditions is selfish. [...] His uneasiness is caused by the awareness of the fact that other people are in want" [71]. But what if helping to relieve other people's wants also causes uneasiness? This, however, is not pertinent to the point I want to make here. In LvM's reasoning, the mechanics of human nature - the operations of the human mind and the motivations of human action - is defined in a manner that allows it to be synchronized with the logic of the competitive market system, while the market system is portrayed as the only viable system for a progressive society based on division of labour. If wanting more and removing uneasiness are together the "springs of human action", this means that "under the particular conditions of dealing on the market, action means buying and selling", i.e., buying at the cheapest price possible, selling at the highest price possible [72] - a reminder: for most to work means to sell yourself on the labour market.

Tension arises within the catallactic system laid out by LvM if one understands the application of "means" and "ends" according to the perfectionist tradition represented 
by $\mathrm{WvH}$. If work is not only understood to be a means to an end, but is also understood to be a medium of one's self-realization, viz. an end in itself, are people under catallactic competition really free to choose and pursue their goals in a manner that enriches their inner being? LvM understands the individuality of man to be an inextinguishable residual [73]. "Ideas that induce a man to make a decision (a choice) are [...] not "uniquely determined' by any ascertainable external factor" [74]. Furthermore, a "capitalist society has no means of compelling a man to change his occupation or his place of work other than to reward those complying with the wants of the consumer by higher pay" [75]. In other words: he who defies the constant productive adjustments has to pay a price, a price, LvM remarks, people are not willing to pay, making them susceptible to socialism [76]. But what if people simply cannot afford to pay this price? Despite LvM's insistence on individual freedom of choice within the catallaxy, man as a businessman is bound to serve the consumer, and is forced to make adjustments accordingly [77]. "For acting man, his own labor is not merely a factor of production but also the source of disutility" [78]. The wage rate indicates to the labourer what kind of work society demands. In capitalism "there prevails a continuous tendency for workers to shift from their branch to other similar occupations in which conditions seem to offer better opportunities" [79]. This follows logically from LvM's praxeology as workers follow higher wages [80]. Zooming out again to the bigger picture of the catallaxy, adjustment mechanisms show that "all groups indirectly compete with one another" [81]. There is no escaping the insecurity that the law of the market generates [82]. "Catallactic competition" (or unhampered capitalist market competition), the omnipresent competition between consumer A, B, C etc. and between producer $\mathrm{X}, \mathrm{Y}, \mathrm{Z}$. etc. "is emulation between people who want to surpass one another" and thereby serve the consumer [83]. "To assign to everybody his proper place in society is the task of the consumer" [84]. Viewed in this way, competition helps to maximize consumption. This and many other claims mentioned are, of course, by no means understood as being undisputed but serve only to understand the catallactic ideology of LvM and FAvH. Only unhampered catallactic competition leads to the Pareto optima displayed by the transformation curve, the locus of the maximum of possible consumption given the price signals generated by the market [85]. A process so abstract and that needs one to consider the whole picture (maximum possible bundles of goods) will not be willingly accepted by those affected by the productive adjustment processes - also known as negative feedback [86]. Consequently, catallactic competition must also perform the role of keeping those ideas that undermine the market competition in check. As LvM is well aware, "ideas held by individuals [...] determine their group allegiance" [87].
For LvM, the human mind tends to imagine more satisfactory material conditions under which man will be able to achieve his goals through individual initiative. As man derives satisfaction from higher remuneration and as he always wants more, ideally, he will be willing to change jobs if relative wages change. It is not his work that binds him, but his pay or his desire for profit. Man's environment affects his pursuit of happiness deeply. And capitalist man has to become as flexible as the market. "The productivity of the capitalist mode of production is the result of the capitalist mindset" [88]. If subjected to market processes, the mindset of man is conditioned by competition. A short passage from FAvH puts this point in a nutshell: "Competition is [...] a method to breed a certain type of mind [...]. The same faculty of thought is going to develop in totally different directions depending on the task it is exposed to" [89]. Catallactic competition and its tendency to foster a certain lifestyle will expose the mind to the same pattern of tasks, i.e. logic, accustoming it to a working life dedicated to the production of means which, in turn, will condition or regulate the mind. I would argue that $\mathrm{WvH}$ would regard the way of life that results from a capitalist market environment as put forward by LvM and FAvH is better suited to machines than it is to men.

\section{WvH: Mans vs. Machine. Keeping the Human Spirit Alive}

In contrast to LvM and FAvH, Karl Marx, like WvH, thought that work could and should be transformed into a source of enjoyment, a solidary endeavour and especially that it should be a source of inner enrichment or self-realization [90]. Human work, therefore, should be organized in a way that not only produces means but is also an end in itself. To explicate WvH's thinking and to contrast his liberalism with that of LvM and FAvH I will focus on a few passages in which $\mathrm{WvH}$ explicitly speaks on the nature of man by comparing it to machines. It will show that the notions of man and machine serve well to distinguish WvH's liberalism from that of LvM and FAvH.

Let me begin with what is probably WvH's most famous quotation: "Man's true purpose - not the one prescribed by unsteady appetites, but by his eternal and invariant reason - is the highest and fullest development of his innate powers to a harmonious whole" [91]. To achieve this monumental task, one must rank one's inner life as supreme. Everything man does reflects back onto his inner being [92]. Man is gifted with the drive to bring his inner being, his selfhood, his own individual personality to the fore, and, by means of his intellectual nature, to combine it with an ideal of self-perfection [93]. He strives for creative self-expression, and in so doing, he also longs to unite with others [94]. But he can only 
properly do so if he has free choice [95]. Why is free choice so important? As an individual, it follows that only man himself knows his true inner needs, or how alienated he feels, or how he wants to spend his energy, or live his life. According to WvH, man's energy is his virtue. "What heightens his energies is of higher value than what simply provides him with material means for his energy" [96]. Only what man is enthusiastic about can serve to heighten his energies. Without energy "man turns into a machine [highlighted, NN]. One might admire what he achieves, but despises what he is." [97]. This is the most crucial point on the anthropological, psychological level. Put simply: man is endowed with a drive to develop his individuality according to non-materialistic ideals, such as seeing other people as being ends in themselves, and finding a way of life where his work becomes an expression of something personal and insofar as this is true, it becomes an end in itself. If man sees his life from a viewpoint other than from striving towards individual (moral) perfection, everything becomes "mechanical" [98]. Man might achieve great things either mechanically or by being motivated by profit, but he will degenerate as a human being. His personality, and with it his dignity and experience of inner beauty, will be effaced. $\mathrm{WvH}$ paints a picture of human nature that could not be more converse to that of LvM's catallactic man. For WvH, material goods only hold value as a prerequisite of inner enrichment. He does not rank consumption very highly: "the labourer who tends a garden, might be in a much truer sense the owner of the garden than the person who relishes in its beauty" [99]. If the source of man's self-worth stems from his achievements - which are achievements of a certain kind - in the market system, his individuality counts only to the degree that it can be harnessed for consuming and producing sellable goods. This way of thinking inevitably transforms man into a factor of production, a function he is supposed to play in LvM's labour market scheme.

Human action, especially active self-realization, is also not seen as the urge to do away with a feeling of uneasiness. WvH sees a human being's individuality as having true value: it is the raw material one has to work with. Competition is harnessed not for material production but for inner and intersubjective enrichment [100]. WvH expresses some concern with the cultural push of his time. Culture as he witnessed it unfolding was more concerned with wealth than with anything else. I allow myself to quote a longer passage here as with some justifiable fantasy it gives us a critical description of the catallaxy: "As it [culture, NN] awackens a lot of new wants and especially aims at achieving as many as possible ends with as little as possible costs, it has placed a plethora of means and instruments between man's energy and the work he achieves with it, instruments which allow a single man to set in motion a big mass with little effort. [...]; the execution of extraordinary enterprises depends now more on the clever calculation of circumstances and the development of clever plans than on the energy and courage of a man's character. The sheer human alone can hardly effect his fellow man and not at all the crowds; he always has to act through the masses, has to transform himself into a machine" [highlighted, NN] [101].

\section{Conclusions}

The analysis of the way LvM's and FAvH's catallaxy organizes production has led to the conclusion that catallactic competition is a way of conditioning the human mind to lead a consumption-centered lifestyle. Preoccupation with means dominates the catallaxy.

Jon Elster contrasted this kind of consumerism with the Marxist "conception of the good life as one of active self-realisation, rather than passive consumption" [102]. Astonishingly, WvH's work shows that on an ethical level, classic liberalism is as critical of neoliberalism as is Marxism. For $\mathrm{WvH}$, if freedom and competition are not related to a perfectionist understanding of human nature, they cannot be properly understood. Man is drained of his energy when he cannot relate to his own work in some intrinsic fashion. His operations become mechanical and he loses his dignity as an individual human being. What a human strives for, according to $\mathrm{WvH}$, are actions that are truly his own. This means that they are of his own choosing, that they are exercised with enthusiasm and that they are characterized by free and manifold intrinsic interaction with his fellow beings [103].

Even if all ethical critique is disposed of by LvM with the argument that no viable alternative to the capitalist mode of production has yet been brought forward, we need to understand the contradictions and ethical shortcomings of the catallactic market system. A system with a cardiac defect will not be as free of interventionism as LvM's liberalism suggests: it will demand the suppression of those who suffer and are prone to rebel. It is apparent that LvM cannot manage to rationalize the liberal system because of the normative stance that "the ends justify the means". It becomes a rather spurious argument from the point of view of Humboldtian liberal perfectionism, if practically the "ends" lie in the catallactically organized production of "means" for profit.

The Austrian school of economics propagates a brand of liberalism - probably the purest and most sophisticated version of neoliberalism - that views the competitive market as the centre of gravity that marshals all of its political institutions to safeguard its continued functioning. Neoliberalism, it seems to me, rather inverts the causal chain of a truly democratic community by submitting the demos to its logic rather than submitting the market system to the demands of the people as consumers and producers. As Sheldon S. Wolin put it: "The so-called free market is not simply about buyers and sellers, or 
producers and owners, but about power relationships that are fundamental to the management of democracy" [104].

Without factoring in the contemporary political and economic institutional settings, no meaningful (=rich, liberal, egalitarian) conception of human flourishing will be able to emerge from analysing what it means to realize one's self. The fault lines endangering the human spirit that $\mathrm{WvH}$ detected at the beginning of the modern age have not disappeared. It might therefore serve us well to take heed of his impassionate warning "that surely no man has ever sunk so low to prefer wealth and happiness to dignity. Whoever tries to convince others of such a preference can be suspected, and with good reason, to misconceive humankind and to want to make machines out of men" [105].

\section{Acknowledgements}

I am most grateful to Prof. Dr. Christine Abbt, the Swiss National Science Foundation (SNSF) and the University of Lucerne for making it possible to write this article. Special thanks to Alison Kappes-Bates.

\section{REFERENCES ${ }^{1}$}

[1] Plato Rep. II 368d-369a, IV 427d-428a.

[2] Rep. VIII 544d-e.

[3] cf. Ch. Horn. Politische Philosophie, in Platon Handbuch. Leben - Werk - Wirkung, ed. by Ch. Horn, J. Müller and J. Söder. Metzler, Stuttgart/Weimar, 2009, 172.

[4] Rep. VIII 546a-547a, VIII 545c-IX 576b.

[5] L. von Mises. Human Action: A Treatise on Economics, Vol.2, Liberty Fund, Indianapolis, 2007 [1949], 259.

[6] ibid., 257-259.

[7] Rep. IV 433a-b.

[8] cf. Ch. Abbt and N. Niazi (eds.). Der Vieltuer und die Demokratie. Politische und philosophische Aspekte von Allotrio- und Polypragmosyne, Colmena, Basel, 2017.

[9] Y. Varoufakis. Why we must save the EU. The European Union is disintegrating - but leaving is not the answer, The Guardian, 2016, Online available from https://www.theguardian.com/world/2016/apr/05/yanis-var oufakis-why-we-must-save-the-eu.

[10] L. von Mises. Human Action, Vol.2, 239.

[11] L. von Mises. The Ultimate Foundations of Economic Science: An Essay on Method, Liberty Fund, Indianapolis,

1 Whenever FAvH and LVM's book Liberalismus is quoted, the translations were mady by the author. Also all quotes from $\mathrm{WvH}$ are translated by the author.
2006 [1962], 83, q.v. 187-189.

[12] ibid., 74.

[13] L. von Mises. Human Action, Vol.2, 265.

[14] ibid., 864.

[15] L. von Mises. Liberalismus, Academia, Sankt Augustin, 2006 [1927], 66-69.

[16] R. A. Dahl. On Democracy, Yale University Press, New Haven, 2000, 166-172, 181.

[17] F. A. von Hayek. Die Verfassung der Freiheit, Mohr Siebeck, Tübingen, 2005 [1960], footnote 24, 77; L. von Mises, Liberalismus, Academia, Sankt Augustin, 2006 [1927], 170.

[18] R. Raico. Wilhelm von Humboldt, New Individualist Review, Vol.1, No.1, 1961, 22-26; F. Hötzl. Wilhelm von Humboldt als Denker der Freiheit, NZZ 11.28.2008, Online available from https://www.nzz.ch/wilhelm_von_humboldt _als_denker_der_freiheit-1.1322811.

[19] L. von Mises. Human Action, Vol.2, 274.

[20] cf. N. Chomsky. Language and Freedom, in Chomsky on Anarchism, ed. by B. Pateman, AK Press, Edinburgh/Oakland/West Virginia, 2005 [1970], 111.

[21] N. Chomsky. Goals and Visions, in Chomsky on Anarchism, ed. by B. Pateman, AK Press, Edinburgh/Oakland/West Virginia, 2005 [1970], 190.

[22] H.-H. Hoppe. Einführung: Ludwig von Mises und der Liberalismus, in Liberalismus, L. von Mises, Academia, Sankt Augustin, 2006 [1927], footnote 24, 34; J. T. Salerno. Ludwig von Mises as Social Rationalist, The Review of Austrian Economics, Vol.4, 1990, 26-54.

[23] F. A. von Hayek. Recht, Gesetz und Freiheit. Eine Neufassung der liberalen Grundsätze der Gerechtigkeit und der politischen Ökonomie, transl. by M. Streissler, ed. by V. Vanberg, Mohr Siebeck, Tübingen, 2003 [1973, 1976, 1979], 260.

[24] L. von Mises. Liberalismus, 3, also 77-80; L. von Mises. Human Action, Vol.2, 242-243.

[25] W. von Humboldt. Ideen zu einem Versuch, die Gränzen der Wirksamkeit des Staats zu bestimmen, in Schriften zur Anthropologie und Geschichte, ed. by A. Flitner and K. Giel, Wissenschaftliche Buchgesellschaft, Darmstadt, 2010 [1792], 64.

[26] L. von Mises. Human Action, Vol.2, 264.

[27] L. v. Mises he Ultimate Foundations of Economic Science: An Essay on Method, Liberty Fund, Indianapolis, 2006 [1962], 115.

[28] R. Rocker. Anarcho-Syndicalism. Theory and Practice, AK Press, Edinburgh/London/Oakland, 2004 [1938].

[29] L. von Mises. Human Action, Vol.2, 265.

[30] L. von Mises. Liberalismus, Academia, Sankt Augustin, 2006 [1927], 3, q.v. 167-168.

[31] ibid., 4.

[32] ibid., 14. 
[33] L. v. Mises. The Ultimate Foundations of Economic Science, 102.

[34] ibid., 102-103.

[35] ibid., 101.

[36] L. von Mises. Human Action, Vol.2, 255.

[37] L. v. Mises. The Ultimate Foundations of Economic Science, 102; L. von Mises. Human Action, Vol.3, 731.

[38] Rep. IV 433a-b.

[39] L. v. Mises. The Ultimate Foundations of Economic Science, 84.

[40] L. von Mises. Human Action, Vol.1, 185.

[41] L. von Mises. Human Action, Vol.2, 319; F. A. von Hayek. Grundsätze einer liberalen Gesellschaftsordnung, in Grundsätze einer liberalen Gesellschaftsordnung. Aufsätze zur Politischen Philosophie und Theorie, ed. by V. Vanberg, 2003 [1966], 80-84.

[42] L. von Mises. Liberalismus, 15, 41, 44-45; F. A. von Hayek. Wirtschaftsfreiheit und repräsentative Demokratie, in Grundsätze einer liberalen Gesellschaftsordnung. Aufsätze zur Politischen Philosophie und Theorie, ed. by V. Vanberg, Mohr Siebeck, Tübingen, 2003 [1973], 180-183.

[43] L. von Mises. Human Action, Vol.2, 237.

[44] ibid., 285.

[45] L. von Mises. Liberalismus, 19, 60.

[46] L. von Mises. Human Action, Vol.2, 281.

[47] ibid., 282.

[48] ibid., 283.

[49] L. von Mises. Liberalismus, 136.

[50] L. von Mises. Human Action, Vol.1, 187.

[51] L. von Mises. Liberalismus, 138.

[52] ibid., 144.

[53] L. v. Mises. The Ultimate Foundations of Economic Science, 114.

[54] L. von Mises. Human Action, Vol.2, 257.

[55] ibid., 283.

[56] ibid., 257.

[57] L. von Mises. Human Action, Vol.1, 179.

[58] L. von Mises. Human Action, Vol.2, 328.

[59] L. v. Mises. The Ultimate Foundations of Economic Science, 115.

[60] L. von Mises. Human Action, Vol.2, 328.

[61] ibid., 329.

[62] L. V. Mises. T The Ultimate Foundations of Economic Science, 115; cf. F. A. von Hayek. Die Verfassung der Freiheit, 274-275.
[63] L. v. Mises. The Ultimate Foundations of Economic Science, 114.

[64] L. von Mises. Human Action, Vol.2, 311-312.

[65] L. von Mises. Liberalismus, 162.

[66] ibid., 165-166.

[67] L. von Mises. Human Action, Vol.1, 13.

[68] L. v. Mises. The Ultimate Foundations of Economic Science, 45; L. von Mises. Human Action, Vol.1, 15.

[69] L. von Mises. Human Action, Vol.1, 15.

[70] ibid.; L. v. Mises. The Ultimate Foundations of Economic Science, 6-7.

[71] L. von Mises. Human Action, Vol.2, 242.

[72] ibid., 240.

[73] L. v. Mises. The Ultimate Foundations of Economic Science, 41.

[74] ibid., 52, q.v. 53.

[75] L. von Mises. Human Action, Vol.2, 286.

[76] ibid., 286.

[77] ibid., 240.

[78] ibid., 592.

[79] ibid., 593.

[80] ibid., 312.

[81] ibid., 593.

[82] ibid., 311.

[83] ibid., 274.

[84] L. von Mises. Human Action, Vol.2, 275; L. v. Mises. The Ultimate Foundations of Economic Science, 79.

[85] F. A. von Hayek. Recht, Gesetz und Freiheit, 268-270.

[86] ibid., 245, 276.

[87] L. v. Mises. The Ultimate Foundations of Economic Science, 74.

[88] L. von Mises. Liberalismus, 76.

[89] F. A. von Hayek. Recht, Gesetz und Freiheit, 382; on the learning ability of the mind cf. L. v. Mises. The Ultimate Foundations of Economic Science, 13; for the same application of the quote from Hayek cf. N. Niazi. Antinomie zweier liberaler Utopien: Wilhelm von Humboldts Thesen zur Bildung des Menschen und die Katallaxie Friedrich August von Hayeks, master thesis (revised version), University of Zurich, 2013, 59. Also consult the master thesis (especially chapter 4) for a similar comparison of old and new liberalism as put forward in this article with an exclusive view on Hayek and an extensive discussion of Humboldt's work.

[90] For a good study on perfectionism and also on Marx perfectionism see Ch. Henning. Freiheit, Gleichheit, 
Entfaltung. Die politische Philosophie des Perfektionismus, Campus, Frankfurt/New York, 2015.

[91] W. von Humboldt. Ideen zu einem Versuch, die Gränzen der Wirksamkeit des Staats zu bestimmen, 64 .

[92] ibid. 75-76.

[93] W. von Humboldt. Das Achtzehnte Jahrhundert, in Schriften zur Anthropologie und Geschichte, ed. by A. Flitner and K. Giel, Wissenschaftliche Buchgesellschaft, Darmstadt, 2010 [1797ff.], 415-416, 476, 479; W. von Humboldt. Über Religion [und Gesetzgebung], in Schriften zur Anthropologie und Geschichte, ed. by A. Flitner and K. Giel, Wissenschaftliche Buchgesellschaft, Darmstadt, 2010 [1790], 13-14.

[94] W. von Humboldt. Ideen zu einem Versuch, die Gränzen der Wirksamkeit des Staats zu bestimmen, 64-66.

[95] ibid., 64.

[96] ibid., 133.

[97] W. von Humboldt. Ideen über Staatsverfassung, durch die neue Französische Constitution veranlasst, in Schriften zur Anthropologie und Geschichte, ed. by A. Flitner and K. Giel, Wissenschaftliche Buchgesellschaft, Darmstadt, 2010 [1791], 37.

[98] W. von Humboldt. Geschichte des Verfalls und Unterganges der griechischen Freistaaten, in Schriften zur Altertumskunde und Ästhetik, ed. by A. Flitner and K. Giel, Wissenschaftliche Buchgesellschaft, Darmstadt, 2010 [1809], 112-113.

[99] W. von Humboldt. Ideen zu einem Versuch, die Gränzen der Wirksamkeit des Staats zu bestimmen, 72-73.

[100] W. von Humboldt. Ideen zu einem Versuch, die Gränzen der Wirksamkeit des Staats zu bestimmen, 64-65, 72.

[101] W. von Humboldt. Ueber Göthes Herrmann und Dorothea, in Schriften zur Altertumskunde und Ästhetik, ed. by A. Flitner and K. Giel, Wissenschaftliche Buchgesellschaft, Darmstadt, 2010 [1798], 341.

[102] J. Elster. Self-realisation in work and politics: the Marxist conception of the good life, in Alternatives to Capitalism, ed. by J. Elster and K. O. Moene, Cambridge University Press, Cambridge, 1993 [1989], 127.

[103] cf. N. Chomsky. Language and Freedom, 110-112.

[104] S. S. Wolin. Democracy Incorporated. Managed Democracy and the Spectre of Inverted Totalitarianism, Princeton University Press, Princeton/Oxford, 2010 [2008], 137.

[105] W. von Humboldt. Ideen zu einem Versuch, die Gränzen der Wirksamkeit des Staats zu bestimmen, 72 . 